\title{
Serum levels of microRNA-371a-3p are not elevated in testicular tumours of non-germ cell origin
}

\author{
Gazanfer Belge ${ }^{1} \cdot$ Francesca Grobelny $^{1} \cdot$ Arlo Radtke $^{1} \cdot$ Jacqueline Bodes $^{1} \cdot$ Cord Matthies $^{2} \cdot$ Christian Wülfing $^{3}$. \\ Klaus-Peter Dieckmann ${ }^{3}$ (1)
}

Received: 15 September 2020 / Accepted: 12 October 2020 / Published online: 16 November 2020

(c) The Author(s) 2020

\begin{abstract}
Purpose Serum levels of microRNA-371a-3p (M371) have been shown to be a highly sensitive and specific biomarker for testicular germ cell tumours (TGCT). Little information exists on the expression of this marker in testicular neoplasms deriving from the gonadal stroma or other structures of the gonad. This study presents an expression analysis of the novel TGCT-biomarker M371 in a large cohort of testicular non-germ cell tumours.

Methods The M371 expression was measured by quantitative real time PCR in serum of 99 patients with testicular tumours of non-germ cell origin, thereof 30 patients with malignant testicular lymphomas and 61 patients with gonadal stroma tumours such as Leydig cell tumours, Sertoli cell tumours and 8 cases with miscellaneous benign testicular tumours. Their M371 levels were compared to those of 20 patients with TGCT and to 37 tumour-free male controls.

Results The median expression levels of benign testicular tumours and testicular lymphoma are close to zero, thus, identical with those of controls and significantly lower than those of TGCT. In summary, this study provides further evidence for the notion that M371 is exclusively expressed by germ cell tumours and not by testicular neoplasms of the non-germ cell subtypes.

Conclusion Clinically, the test might be of value in preoperative characterization of benign testicular tumours eligible for conservative surgery.
\end{abstract}

Keyword Biomarker $\cdot$ miR-371a-3p $\cdot$ Non-germ cell tumour $\cdot$ Malignant lymphoma $\cdot$ Leydig cell tumour $\cdot$ Sertoli cell tumour

$\begin{array}{ll}\text { Abbreviations } \\ \text { AFP } & \text { Alpha fetoprotein } \\ \text { AUC } & \text { Area under the curve } \\ \text { bHCG } & \text { Beta human chorionic gonadotropin } \\ \text { LDH } & \text { Lactate dehydrogenase } \\ \text { cDNA } & \text { Complementary DNA } \\ \text { CS } & \text { Clinical Stage }\end{array}$

Gazanfer Belge and Francesca Grobelny contributed equally to this work.

Klaus-Peter Dieckmann

dieckmannkp@gmail.com

1 Faculty of Biology and Chemistry, University of Bremen, Bremen, Germany

2 Department of Urology, Bundeswehrkrankenhaus Hamburg, Hamburg, Germany

3 Department of Urology, Asklepios Klinik Altona, Paul-Ehrlich-Str. 1, 22763 Hamburg, Germany
EC Embryonal carcinoma

GST Gonadal stroma tumour

IQR Interquartile range

M371 MicroRNA-371a-3a

miR MicroRNA

NS Nonseminoma

qPCR Quantitative real-PCR

ROC Receiver operating characteristic

RQ Relative quantity

SPSS Statistical package for the social sciences

TGCT Testicular germ cell tumour

YST Yolk sac tumour

\section{Introduction}

Testicular germ cell tumours (TGCTs) represent a paradigm of a curable malignancy (Rajpert-De Meyts et al. 2016). Clinical management of TGCTs is extensively guided by 
imaging technologies e.g. computed tomography or magnetic resonance imaging and by serum levels of tumour markers alpha fetoprotein (AFP), beta Human chorionic gonadotropin (bHCG) and lactate dehydrogenase (LDH) (Albers et al. 2015; Honecker et al. 2018; Lembeck et al. 2020). Unfortunately, the utility of the classical tumour markers is compromised by their low sensitivity. Recently, serum levels of microRNA-371a-3p (so called M371 test) have been shown to greatly outperform the classical markers with a sensitivity of $90 \%$ and a specificity of around 94\% (Almstrup et al. 2020; Dieckmann et al. 2019; Lobo et al. 2019; Terbuch et al. 2018). Histologically, 90\% of all testicular tumours are of germ cell origin. The remainder comprises of an extraordinarily wide variety of rare neoplasms (Idrees et al. 2017; Mooney and Kao 2018). The most frequent subgroup of non-germ cell tumours develop from the gonadal stroma such as Leydig cell tumours, Sertoli cell tumours and granulosa cell tumours including cases with mixed forms and unspecified stromal tumours. More than $90 \%$ of these neoplasms are of benign nature (Ruf et al. 2020). The other major subgroup of testicular non-germ cell tumours comprises of so-called haematolymphoid tumours with diffuse large B-Cell lymphoma representing the most frequent subtype followed by follicular lymphoma and rare hematological malignancies such as plasmacytoma and others. The WHO also lists a group of miscellaneous neoplasms with excessively rare incidences that mainly comprise of ovarian epithelial-type tumours with testicular thecoma representing one of these. To complete the list of non-germ cell neoplasms of the testis, the excessively rare and highly malignant carcinoma of the rete testis must be noted as well as metastases of other malignancies to the testicle (Dieckmann et al. 1988). The clinical management of non-germ cell tumours of the testis is hampered by the unpredictable natural course of many of these neoplasms and by the lack of a serum biomarker for assessing the state of the disease (Banerji et al. 2016; Fankhauser et al. 2019; Kern et al. 2020). It was shown that M371 is not or only very little expressed by extra-testicular malignancies (Spiekermann et al. 2015), but there are currently limited data regarding the expression of this novel marker in testicular neoplasms of non-germ cell origin (Regouc et al. 2020). The present study analyses serum levels of M371 in a large patient sample of non-germ cell testicular tumours with several histological subgroups and compares the findings with the levels in patients with TGCT.

\section{Materials and methods}

\section{Patients for serum investigations}

A total of 99 patients with non-germ cell tumours of the testis underwent cubital vein blood aspiration for analysis. The patient population involved the following histological subgroups: Leydig cell tumour ( $n=40$, median age 43.0 years),
Sertoli cell tumours ( $n=18$, median age 40.5 years), Granulosa cell tumour ( $n=2$, median age 27.0 years) and one unspecified gonadal stroma tumour (age 21 years) as well as testicular adenomatoid tumours $(n=6$, median age 34.0 years), testicular hemangioma $(n=2$, median age 72.5 years $)$ and malignant testicular lymphoma $(n=30$, median age 69.5 years) (Table 1 ). The majority of patients were recruited from Hamburg-based hospitals: AlbertinenKrankenhaus, Asklepios Klinik Altona, and Bundeswehr Krankenhaus during 2015-2019. A few additional cases were originally recruited by other institutions for a multicentric study on GCT patients but excluded from that evaluation because of their non-GCT histology (Dieckmann et al. 2019). All serum samples were collected preoperatively. Twenty patients with testicular germ cell tumour (14 seminoma, 6 nonseminoma; median age 34.5 years) (Table 2), and 37 tumour-free males (median age 40.0 years) served as controls (Table 3).

All patients gave informed consent. The study had been ethically approved by Ärztekammer Bremen (\#301, decisions Jul 08 and Oct 08, 2015). All study activities had been conducted according to the Declaration of Helsinki of the World Medical Association (as amended by the 64th General Assembly, 2013).

\section{Measurement of serum levels of miRNA}

Serum was obtained after centrifugation of whole blood samples. Serum was kept deep-frozen at $-80^{\circ}$ Celsius until shipping to the study laboratory (University of Bremen) where the samples were further kept deep-frozen until final processing.

The measurement of M371 expression levels in serum was performed as previously described (Dieckmann et al. 2019). Briefly, the total RNA was isolated from $200 \mu \mathrm{L}$ serum using the miRNeasy Mini Kit according to the supplied protocol (Qiagen, Hilden, Germany). For reverse transcription of microRNA into complementary DNA (cDNA), $6 \mu \mathrm{L}$ total RNA were added to the master mix of the TaqMan Reverse Transcription Kit including specific microRNA stem-loop primers of miR-371a-3p and miR-30b-5p (Applied Biosystems, Darmstadt, Germany). The reaction was performed in the Mastercycler gradient (Eppendorf, Hamburg, Germany) for $30 \mathrm{~min}$ at $16^{\circ} \mathrm{C}, 30 \mathrm{~min}$ at $42^{\circ} \mathrm{C}$ and $5 \mathrm{~min}$ at $85^{\circ} \mathrm{C}$. A preamplification was performed using the cDNA and 1:100 diluted TaqMan Assays for miR-371a-3p (assay ID 002124) and miR-30b-5p (assay ID 000432). MicroRNA expression was finally quantified on 7500 Fast Real-Time PCR System (Applied Biosystems, Darmstadt, Germany) using FAST Start Universal Probe Master (Roche Diagnostics, Mannheim, Germany). Serum levels of M371 were measured relative to endogenous control miR-30b-5p. The final RQ 
Table 1 Clinical data and relative M371 expression in serum of patients with testicular non-germ cell tumours

\begin{tabular}{|c|c|c|c|c|}
\hline Patient ID & Age (years) & Dignity & Histology & RQ M371 \\
\hline 1 & 30 & Benign & Leydig cell tumor & 0.00 \\
\hline 2 & 47 & Benign & Leydig cell tumor & 0.00 \\
\hline 3 & 22 & Benign & Leydig cell tumor & 0.00 \\
\hline 4 & 44 & Benign & Leydig cell tumor & 0.00 \\
\hline 5 & 52 & Benign & Leydig cell tumor & 0.00 \\
\hline 6 & 64 & Benign & Leydig cell tumor & 0.00 \\
\hline 7 & 44 & Benign & Leydig cell tumor & 0.00 \\
\hline 8 & 39 & Benign & Leydig cell tumor & 0.00 \\
\hline 9 & 37 & Benign & Leydig cell tumor & 0.00 \\
\hline 10 & 29 & Benign & Leydig cell tumor & 0.00 \\
\hline 11 & 42 & Benign & Leydig cell tumor & 0.00 \\
\hline 12 & 31 & Benign & Leydig cell tumor & 0.00 \\
\hline 13 & 42 & Benign & Leydig cell tumor & 0.00 \\
\hline 14 & 36 & Benign & Leydig cell tumor & 0.75 \\
\hline 15 & 69 & Benign & Leydig cell tumor & 0.00 \\
\hline 16 & 69 & Benign & Leydig cell tumor & 0.00 \\
\hline 17 & 39 & Benign & Leydig cell tumor & 0.00 \\
\hline 18 & 39 & Benign & Leydig cell tumor & 6.96 \\
\hline 19 & 28 & Benign & Leydig cell tumor & 0.00 \\
\hline 20 & 28 & Benign & Leydig cell tumor & 0.00 \\
\hline 21 & 34 & Benign & Leydig cell tumor & 0.00 \\
\hline 22 & 50 & Benign & Leydig cell tumor & 0.00 \\
\hline 23 & 46 & Benign & Leydig cell tumor & 0.00 \\
\hline 24 & 51 & Benign & Leydig cell tumor & 0.99 \\
\hline 25 & 37 & Benign & Leydig cell tumor & 0.74 \\
\hline 26 & 37 & Benign & Leydig cell tumor & 0.00 \\
\hline 27 & 49 & Benign & Leydig cell tumor & 1.82 \\
\hline 28 & 38 & Benign & Leydig cell tumor & 0.00 \\
\hline 29 & 79 & Benign & Leydig cell tumor & 0.00 \\
\hline 30 & 32 & Benign & Leydig cell tumor & 0.00 \\
\hline 31 & 33 & Benign & Leydig cell tumor & 0.00 \\
\hline 32 & 61 & Benign & Leydig cell tumor & 0.00 \\
\hline 33 & 64 & Benign & Leydig cell tumor & 0.43 \\
\hline 34 & 53 & Benign & Leydig cell tumor & 2.17 \\
\hline 35 & 64 & Benign & Leydig cell tumor & 0.00 \\
\hline 36 & 40 & Benign & Leydig cell tumor & 0.00 \\
\hline 37 & 49 & Benign & Leydig cell tumor & 0.00 \\
\hline 38 & 44 & Benign & Leydig cell tumor & 0.00 \\
\hline 39 & 50 & Benign & Leydig cell tumor & 0.00 \\
\hline 40 & 49 & Benign & Leydig cell tumor & 0.50 \\
\hline 41 & 31 & Benign & Sertoli cell tumor & 0.00 \\
\hline 42 & 40 & Benign & Sertoli cell tumor & 0.00 \\
\hline 43 & 62 & Benign & Sertoli cell tumor & 0.00 \\
\hline 44 & 18 & Benign & Sertoli cell tumor & 0.00 \\
\hline 45 & 47 & Benign & Sertoli cell tumor & 0.00 \\
\hline 46 & 48 & Benign & Sertoli cell tumor & 0.00 \\
\hline 47 & 26 & Benign & Sertoli cell tumor & 0.00 \\
\hline 48 & 29 & Benign & Sertoli cell tumor & 0.00 \\
\hline 49 & 37 & Benign & Sertoli cell tumor & 0.00 \\
\hline
\end{tabular}

Table 1 (continued)

\begin{tabular}{|c|c|c|c|c|}
\hline Patient ID & Age (years) & Dignity & Histology & RQ M371 \\
\hline 50 & 55 & Benign & Sertoli cell tumor & 0.00 \\
\hline 51 & 37 & Benign & Sertoli cell tumor & 0.00 \\
\hline 52 & 41 & Benign & Sertoli cell tumor & 0.00 \\
\hline 53 & 26 & Benign & Sertoli cell tumor & 0.00 \\
\hline 54 & 43 & Benign & Sertoli cell tumor & 2.35 \\
\hline 55 & 18 & Benign & Sertoli cell tumor & 0.00 \\
\hline 56 & 67 & Benign & Sertoli cell tumor & 0.00 \\
\hline 57 & 51 & Benign & Sertoli cell tumor & 0.00 \\
\hline 58 & 49 & Benign & Sertoli cell tumor & 0.71 \\
\hline 59 & 32 & Benign & $\begin{array}{l}\text { Granulosa cell } \\
\text { tumor }\end{array}$ & 0.00 \\
\hline 60 & 22 & Benign & $\begin{array}{l}\text { Granulosa cell } \\
\text { tumor }\end{array}$ & 0.00 \\
\hline 61 & 21 & Benign & Unspecified GST & 0.32 \\
\hline 62 & n.a & Benign & $\begin{array}{l}\text { Adenomatoid } \\
\text { tumor }\end{array}$ & 0.00 \\
\hline 63 & 29 & Benign & $\begin{array}{l}\text { Adenomatoid } \\
\text { tumor }\end{array}$ & 0.00 \\
\hline 64 & 51 & Benign & $\begin{array}{l}\text { Adenomatoid } \\
\text { tumor }\end{array}$ & 0.81 \\
\hline 65 & 34 & Benign & $\begin{array}{l}\text { Adenomatoid } \\
\text { tumor }\end{array}$ & 0.00 \\
\hline 66 & 34 & Benign & $\begin{array}{l}\text { Adenomatoid } \\
\text { tumor }\end{array}$ & 0.00 \\
\hline 67 & 44 & Benign & $\begin{array}{l}\text { Adenomatoid } \\
\text { tumor }\end{array}$ & 0.00 \\
\hline 68 & 81 & Benign & Hemangioma & 0.00 \\
\hline 69 & 64 & Benign & Hemangioma & 0.00 \\
\hline 70 & 74 & Malignant & Lymphoma & 0.00 \\
\hline 71 & 66 & Malignant & Lymphoma & 0.00 \\
\hline 72 & 70 & Malignant & Lymphoma & 0.00 \\
\hline 73 & n.a & Malignant & Lymphoma & 0.00 \\
\hline 74 & $\mathrm{n} . \mathrm{a}$ & Malignant & Lymphoma & 0.00 \\
\hline 75 & 74 & Malignant & Lymphoma & 0.00 \\
\hline 76 & 83 & Malignant & Lymphoma & 0.00 \\
\hline 77 & 89 & Malignant & Lymphoma & 0.00 \\
\hline 78 & 46 & Malignant & Lymphoma & 0.00 \\
\hline 79 & 53 & Malignant & Lymphoma & 0.00 \\
\hline 80 & 69 & Malignant & Lymphoma & 0.00 \\
\hline 81 & 27 & Malignant & Lymphoma & 0.00 \\
\hline 82 & 76 & Malignant & Lymphoma & 0.00 \\
\hline 83 & 62 & Malignant & Lymphoma & 3.03 \\
\hline 84 & 40 & Malignant & Lymphoma & 0.00 \\
\hline 85 & 80 & Malignant & Lymphoma & 8.34 \\
\hline 86 & 76 & Malignant & Lymphoma & 0.00 \\
\hline 87 & 61 & Malignant & Lymphoma & 0.00 \\
\hline 88 & 67 & Malignant & Lymphoma & 0.00 \\
\hline 89 & 61 & Malignant & Lymphoma & 2.23 \\
\hline 90 & 85 & Malignant & Lymphoma & 0.00 \\
\hline 91 & 71 & Malignant & Lymphoma & 2.06 \\
\hline 92 & 68 & Malignant & Lymphoma & 0.00 \\
\hline
\end{tabular}


Table 1 (continued)

\begin{tabular}{llllc}
\hline Patient ID & Age (years) & Dignity & Histology & RQ M371 \\
\hline 93 & 70 & Malignant & Lymphoma & 0.00 \\
94 & 55 & Malignant & Lymphoma & 25.28 \\
95 & 52 & Malignant & Lymphoma & 0.00 \\
96 & 69 & Malignant & Lymphoma & 0.00 \\
97 & 87 & Malignant & Lymphoma & 4.26 \\
98 & 77 & Malignant & Lymphoma & 0.00 \\
99 & 99 & Malignant & Lymphoma & 9.19 \\
\hline
\end{tabular}

$R Q$ Relative quantity, GST gonadal stroma tumor, n.a. not available

was calculated by means of the $2-\Delta \Delta \mathrm{CT}$ method according to Livak and Schmittgen (2001).

\section{Statistical methods}

The statistical evaluation was carried out with SPSS version 26 (IBM, Armonk, NY, USA). Receiver operating characteristic curves (ROC) were calculated to document the ability of the M371 test to discriminate GCTs from non-germ cell testicular tumours. Spearman correlation was calculated to explore for correlation of RQ values with age of patients. For the analysis of differences between two independent variables, the Mann-Whitney U test was used. Significance was assumed at $p<0.05$.

\section{Results}

In the majority of cases with benign non-germ cell tumours, M371 was undetectable in serum (Fig. 1). The median expression level (relative quantity, RQ) in serum of this subgroup thus is $\mathrm{RQ}=0$ (interquartile range, $\mathrm{IQR}=0$ ) which is not different from controls $(\mathrm{RQ}=0 ; \mathrm{IQR}=0 ; p=0.659)$, while TGCT patients had a significantly higher median RQ of 195.54 with an IQR of 717.22-16.91( $p=3.21 * 10-14)$. Likewise, malignant lymphoma had a median expression level of $R Q=0$ (IQR $=0.515-0.000)$, not different from controls $(p=0.206)$ but significantly lower than the median value of TGCT patients ( $p=1.97 * 10-11)$ (Table 4$)$. Notably, seven patients with malignant lymphoma had somewhat elevated RQ values (outliers in Fig. 1, Table 1), however, these isolated cases did not affect the median RQ value of this subgroup and only three of them ranged above the cut-off level of $R Q=5$. Noteworthy, the second highest RQ of 9.19 among the patients with testicular lymphoma was observed in the oldest of these patients. He was 99 years of age and he had bilateral disease. A Spearman correlation revealed that age of the patients does not correlate with RQ $(p=0.395)$.
Table 2 Clinical data and relative M371 expression of serum from analysed patients with malignant testicular germ cell tumours

\begin{tabular}{lllllr}
\hline Patient ID & Age (years) & Histology & $\begin{array}{l}\text { Tumour } \\
\text { size }(\mathrm{mm})\end{array}$ & Clinical stage & RQ M371 \\
\hline 100 & 29 & Seminoma & 30 & CS3 & 734.19 \\
101 & 44 & Seminoma & 85 & CS2 & 666.29 \\
102 & 44 & Seminoma & 26 & CS1 & 24.25 \\
103 & 40 & Seminoma & 22 & CS1 & 24.08 \\
104 & 35 & Seminoma & 15 & CS1 & 4.02 \\
105 & 50 & Seminoma & 48 & CS1 & 238.86 \\
106 & 56 & Seminoma & 19 & CS1 & 1.58 \\
107 & 19 & NS (80\% Teratoma, 20\% YST) & 180 & CS3 & 8779.97 \\
108 & 30 & Seminoma & 29 & CS1 & 12.21 \\
109 & 37 & Seminoma & 68 & CS1 & 374.81 \\
110 & 36 & Seminoma & 22 & CS1 & 46.53 \\
111 & 26 & Seminoma & 46 & CS2 & 760.08 \\
112 & 41 & Seminoma & 24 & CS1 & 8.46 \\
113 & 36 & Seminoma & 32 & CS1 & 359.54 \\
114 & 25 & NS (EC) & 26 & CS2 & 2574.36 \\
115 & 21 & NS (90\% YST, 10\% EC) & 37 & CS1 & 125.37 \\
116 & 33 & Seminoma & 24 & CS1 & 14.52 \\
117 & 25 & NS (EC) & 24 & CS1 & 2033.85 \\
118 & 34 & NS (EC) & n.a & CS2 & 15.22 \\
119 & 31 & NS (EC) & 25 & CS2 & 588.13 \\
\hline
\end{tabular}

$C S$ Clinical stage, EC Embryonal carcinoma, NS Non seminoma, YST Yolk sac tumor, $R Q$ Relative quantity, n.a. not available 
Table 3 Clinical data and relative M371 expression of serum from analyzed tumour-free patients which served as controls

\begin{tabular}{|c|c|c|c|}
\hline Patient ID & Age (years) & Diagnosis & RQ M371 \\
\hline 120 & 31 & Hydrocele & 0.00 \\
\hline 121 & 67 & Epididymitis & 0.00 \\
\hline 122 & 27 & Testicular pain & 0.00 \\
\hline 123 & 67 & Spermatocele & 0.00 \\
\hline 124 & 21 & Prostatitis & 0.00 \\
\hline 125 & 23 & Gonadal dysgenesis & 0.00 \\
\hline 126 & 49 & Infertility & 0.33 \\
\hline 127 & 20 & Varicocele & 0.00 \\
\hline 128 & 33 & Testicular pain & 0.72 \\
\hline 129 & 41 & Epididymitis & 0.00 \\
\hline 130 & 40 & Infertility & 0.00 \\
\hline 131 & 24 & Infertility & 0.00 \\
\hline 132 & 61 & Infertility & 0.00 \\
\hline 133 & 55 & Infertility & 0.00 \\
\hline 134 & 37 & Infertility & 0.00 \\
\hline 135 & 38 & Testicular microlithiasis & 0.00 \\
\hline 136 & 45 & Infertility & 0.00 \\
\hline 137 & 32 & Infertility & 0.00 \\
\hline 138 & 31 & Infertility & 0.00 \\
\hline 139 & 79 & Epididymitis & 0.00 \\
\hline 140 & 40 & Azoospermia & 0.00 \\
\hline 141 & 38 & Chronic testicular pain & 0.00 \\
\hline 142 & 70 & Chronic testicular pain & 0.00 \\
\hline 143 & 24 & Chronic testicular pain & 0.00 \\
\hline 144 & 54 & Epididymitis & 0.00 \\
\hline 145 & 39 & Epididymitis & 2.50 \\
\hline 146 & 42 & Epididymitis & 0.00 \\
\hline 147 & 74 & Orchitis & 7.11 \\
\hline 148 & 43 & Epididymitis & 0.00 \\
\hline 149 & 79 & Epididymitis & 0.00 \\
\hline 150 & 63 & Testicular pain & 0.00 \\
\hline 151 & 62 & Epididymitis & 0.00 \\
\hline 152 & 62 & Epididymitis & 0.00 \\
\hline 153 & 50 & Epididymitis & 0.66 \\
\hline 154 & 24 & Chronic testicular pain & 0.00 \\
\hline 155 & 32 & Epididymitis & 0.00 \\
\hline 156 & 39 & Epididymitis & 0.00 \\
\hline
\end{tabular}

$R Q$ Relative quantity

Both of the other outliers with RQ values above the cut-off of $\mathrm{RQ}=5$, had the rare lymphoma subtype of plasmacytoma, histologically, and both had extended disease with multiorgan affections, clinically.

Separate analyses of the various histologic subgroups of benign tumours revealed that median M371 levels are zero or close to zero $(\mathrm{RQ}=0.00)$ in serum of patients with any of the histologic subtypes (Fig. 2). The median RQ value of all of the analysed subgroups with testicular tumours of non-germ cell origin is identical with controls, and all subgroups have significantly lower median expression levels of M371 than TGCT $(p<0.001)$. Dieckmann et al. (2017) suggested a RQ of 5.00 to represent an optimal cutoff. In this study within the group of Leydig cell tumours, only one of the eight outliers is located above that cutoff with a RQ of 6.96 but this did not affect the median M371 expression of the group of 0.00 $(\mathrm{IQR}=0)$. Likewise, the three outliers within the group of 21 other gonadal stroma tumours (median $\mathrm{RQ}=0 ; \mathrm{IQR}=0$ ) are close to the median and clearly below the cutoff (Table 4).

The Receiver operating characteristic curves (ROC) based on patients with testicular germ cell tumours $(n=20)$ and the entire group of all other investigated patients with different diseases $(n=136)$ revealed an area under the curve (AUC) of 0.991 (Fig. 3a). With a cutoff of RQ =5.0, TGCT patients can thus be discriminated from all other histologies with a diagnostic sensitivity of $96.32 \%$ and a specificity of 90\%. Further ROC analyses revealed an AUC of 0.996 with a sensitivity of 98.55 (Fig. 3b), an AUC of 0.972 with a sensitivity of $90.00 \%$ (Fig. 3c), and an AUC of 0.996 with a with a sensitivity of 97.30 (Fig. 3d) when TGCT patients were plotted against patients with benign testicular tumours $(n=69)$, lymphomas $(n=30)$, and control patients $(n=37)$, respectively (all details in composite Fig. 3).

\section{Discussion}

The central result of the present investigation is that nongerm cell neoplasms of the testis do not engender significant elevations of M371 serum levels.

Lower microRNA (miR)-levels in Leydig cell tumours than in TGCTs had already been briefly documented previously (Syring et al. 2015; Dieckmann et al. 2017). However, the present report represents a systematic investigation of a larger number of patients with various types of non-germ cell testicular tumours. The very low or non-expression of M371 in non-germ cell testicular tumours is consistent with the non-expression of this microRNA found in extratesticular malignancies (Spiekermann et al. 2015). Originally, M371 was shown to be characteristic for human embryonic stem cells (Pfaff et al. 2012; Suh et al. 2004). Subsequent investigations found a strong expression of this miR also in germ cell tumours (Belge et al. 2020; Palmer et al. 2010) and it was assumed that the biological similarity of human stem cells and germ cell neoplasms would be the reason for the particular miR profile of testicular tumours (Bezan et al. 2014; Looijenga et al. 2014). In line with that view is the lack of M371 expression in teratoma, because this TGCT subtype represents a much more differentiated, mature neoplasm with almost no features in common with embryonic stem cells (Lobo et al. 2019). 
Fig. 1 M371 expression in serum of controls and testicular tumours of different histologic subtypes. Boxplots indicate the median relative M371 expressions with interquartile ranges in the various subgroups. Stars represent statistical outliers.

The median M371 expression in malignant germ cell tumors is significantly higher than the expressions in controls and in tumours of non-germ cell origin $(* * * p<0.001)$. The $y$-axis is shown in a logarithmic scale
Table 4 Relative expression of M371 in various histological groups of non-germ cell testicular tumours

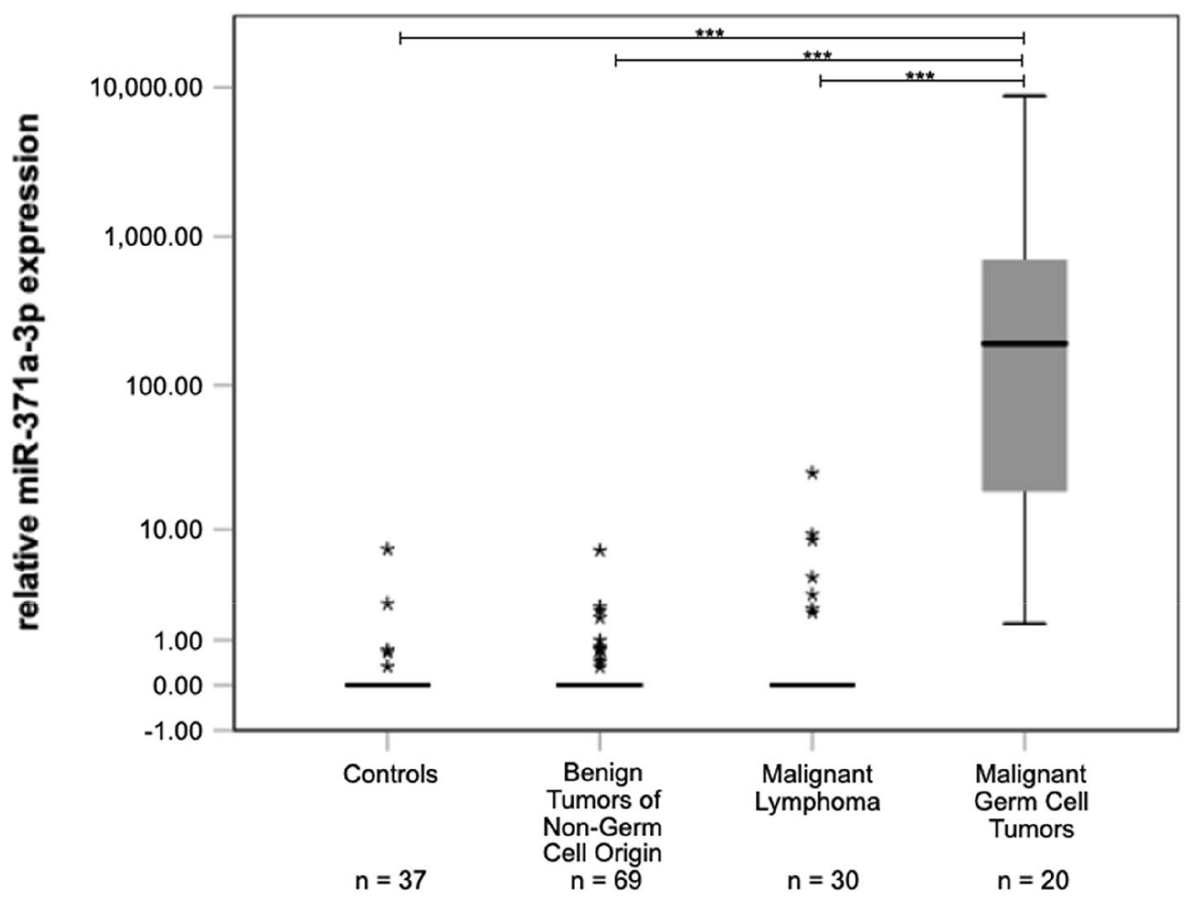

\begin{tabular}{llllllll}
\hline & Controls & LC tumours & $\begin{array}{l}\text { Other GS } \\
\text { tumours }\end{array}$ & $\begin{array}{l}\text { Adeno- } \\
\text { matoid } \\
\text { tumours }\end{array}$ & Hemangioma & Lymphoma & TGCT \\
\hline$n$ & 37 & 40 & 21 & 6 & 2 & 30 & 20 \\
RQ median & 0.00 & 0.00 & 0.00 & 0.00 & 0.00 & 0.00 & 195.54 \\
RQ minimum & 0.00 & 0.00 & 0.00 & 0.00 & 0.00 & 0.00 & 1.58 \\
RQ maximum & 7.11 & 6.96 & 2.35 & 0.81 & 0.00 & 25.28 & 8779.97 \\
25th percentile & 0.00 & 0.00 & 0.00 & 0.00 & 0.00 & 0.00 & 16.91 \\
75th percentile & 0.00 & 0.00 & 0.00 & 0.20 & 0.00 & 0.52 & 717.22 \\
\hline
\end{tabular}

$R Q$ Relative quantity, $G S$ gonadal stroma tumour, $T G C T$ testicular germ cell tumours, $I Q R$ Interquartile Range

Accordingly, Leydig cell tumours and all other histologic subtypes analysed herein are quite different from embryonic stem cells and from germ cell neoplasms likewise. This dissimilarity regarding morphologic and biologic characteristics is probably the underlying reason for the non-expression of M371 in non-germ cell testicular tumours.

Clinically, the lacking M371 expression of non-germ cell testicular tumours may be a useful tool for preoperative assessment of small testicular neoplasms. It has been shown, that testicular tumours less than $1 \mathrm{~cm}$ in size represent benign non-germ cell neoplasms, histologically, in almost two-thirds of the cases (Scandura et al. 2017). Traditionally, every case with suspected testicular neoplasm including all small neoplasms has been considered a candidate for explorative surgery or even orchiectomy (Peckham 1988; Weissbach et al. 1985). With the evergrowing number of incidentally detected cases of small testicular neoplasms, it became clear that many of these cases are of benign nature and would, therefore, require only a conservative surgical approach or even no surgery at all (Dieckmann et al. 2013; Paffenholz et al. 2018). However, approximately $15-20 \%$ of all small testicular neoplasms $<1 \mathrm{~cm}$ still represent malignant germ cell tumours (Gentile et al. 2020), and therefore the general recommendation for surveillance of small tumours has remained a matter of debate (Ates et al. 2016; Kern et al. 2020; Laclergerie et al. 2018).

The M371 test could aid in clinical decision-making in this setting. The majority of small germ cell tumours $<1 \mathrm{~cm}$ of size have shown themselves to instigate elevated M371 serum levels which is particularly true in nonseminomatous tumours. Pure seminomatous tumours have weaker expression of miR, but still $50 \%$ of small seminomas show measurable miR-levels (Dieckmann et al. 2019). 


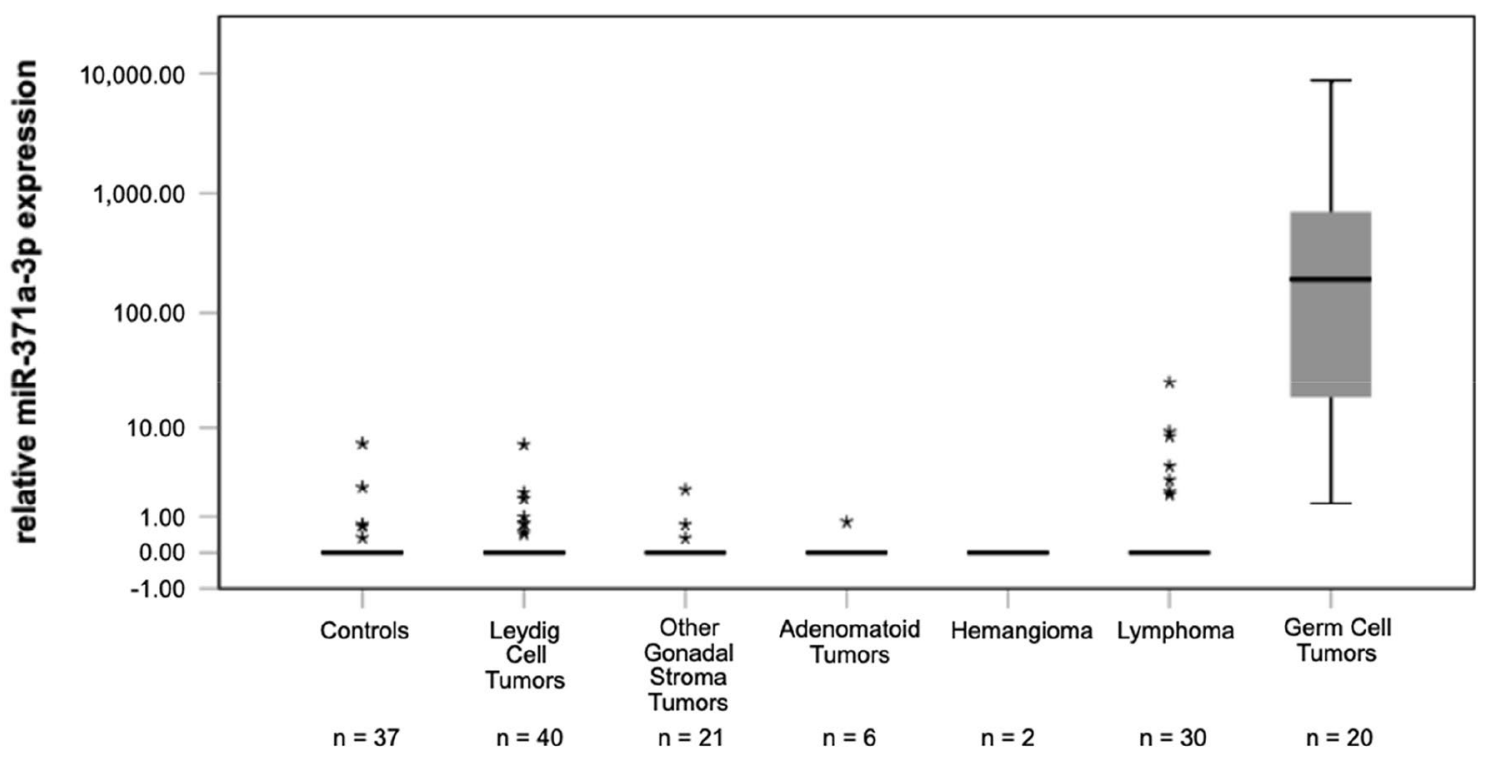

Fig. 2 Relative M371 expression in serum of controls, testicular germ cell tumors and in various benign testicular tumours of non-germ origin. Boxplots indicate the median relative M371 expression with interquartile ranges. The subgroup of other gonadal stroma tumours includes Sertoli cell tumours $(n=18)$, Granulosa cell tumours $(n=2)$

Conversely, a negative M371 test found in a patient with a small testicular tumour would thus support the assumption of a benign non-germ cell neoplasm. Accordingly, the negative M371 test might thus allow for clinical decisionmaking towards a conservative surgical approach or even a surveillance strategy in appropriate cases.

The very low or lacking expression of M371 was consistently found among the various histologic subtypes of non-germ cell testicular tumours analysed herein. Of note, we found somewhat elevated miR-levels in seven patients with malignant lymphoma, but only three of whom had elevations above the cut-off of $R Q=5$. Curiously, among these three outliers was the oldest patient aged 99 years who had bilateral testicular lymphoma. He had the second highest RQ value of 9.19. An additional explorative analysis revealed that there is no correlation of RQ values with age in testicular lymphoma. An association of RQ values with tumour load in testicular lymphoma or specific histological subtypes remains conceivable, since two of the outliers had the rare subtype of plasmacytoma and both of whom had extended disease. However, this hypothesis could not be further substantiated in our study because of lacking data on tumour load in the other cases. Currently, there is no clear biological explanation for the number of outliers. At least five outliers were observed among controls, too. Therefore, these somewhat elevated miR levels in a few patients with testicular lymphoma may well reflect the natural scattering of miR-levels and thus most probably represent chance findings. and one unspecified gonadal stroma tumour. Statistical outliers are represented by stars. The median M371 expression of germ cell tumours is significantly higher than that of controls and of each of the other subgroups, respectively $(* * * p<0.001)$. The $\mathrm{y}$-axis is plotted in a logarithmic scale

The present study is certainly not without limitations. Small patient numbers among the histologic subgroups and the retrospective patient accrual are probably the most important limitations. However, as the neoplasms analysed in this study represent truly rare diseases, there is clearly no other way of recruiting such patients for analysis. Thus, the sample sizes appear quite reasonable. A theoretical drawback could be long deep-frozen storage time of serum samples and long shipping times from bedside to laboratory with putative loss of microRNA content. The group of malignant testicular lymphoma was not systematically subdivided, histologically, although several particular subtypes may occur. It remains thus unknown if the outliers in the lymphoma group belong to specific histologic subtypes.

\section{Conclusions}

Non-germ cell tumours of the testis have very low to zero expression of M371 in serum. The present study confirms that the expression of this miR is highly specific for germ cell neoplasms but not for testicular tumours in general. This result might be of value clinically, as in incidentally detected small testicular neoplasms, a negative M371 test could support the diagnosis of a benign non-germ cell tumour and thus facilitate clinical decision-making in favor of conservative surgery or surveillance of small testicular tumours. 

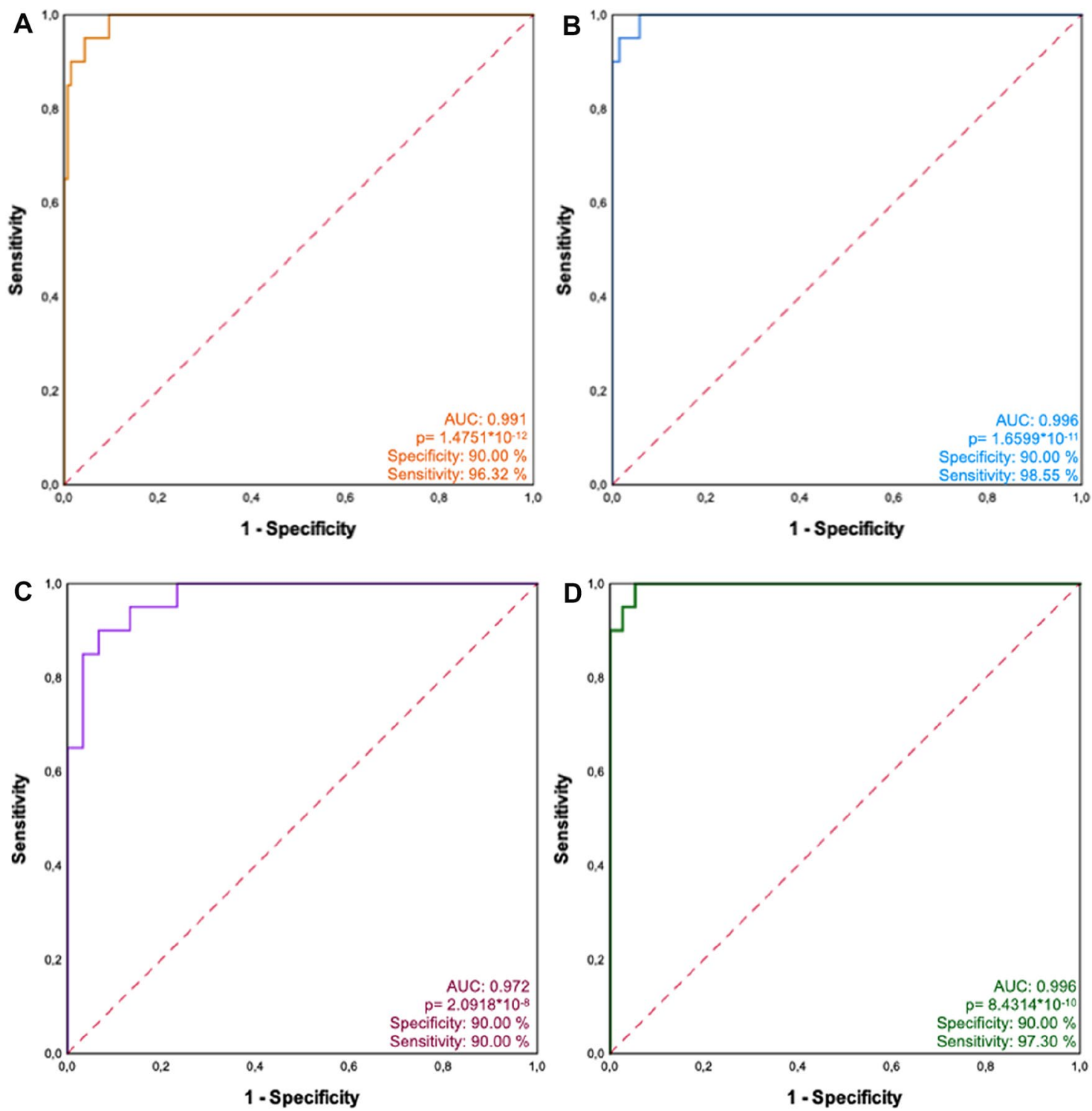

Fig. 3 Discriminative ability of M371. ROC curves showing the high sensitivity and specificity of the M371 test for detecting TGCT $(n=20)$ by comparison to (a) the entire group of other patients $(n=136$; AUC, 0.991), b patients with benign testicular tumours of non-germ cell origin $(n=69$; AUC, 0.996), $\mathbf{c}$ patients with testicular

Acknowledgements We gratefully acknowledge the advice offered by Mrs. Beverly von Bruch, University of Bremen, and the technical assistance provided by the laboratory staffs of Asklepios Klinik Altona, and Albertinen-Krankenhaus, Hamburg.

Author contributions Conceptualization, GB, KPD, FG and AR; methodology, JB, FG; validation, FG; formal analysis, FG; investigation, $\mathrm{KPD}, \mathrm{CM}, \mathrm{CW}$; resources, GB; data curation, $\mathrm{GB}, \mathrm{KPD}, \mathrm{CM}$, $\mathrm{CW}$; writing - original draft preparation, GB, KPD, FG and AR; visualization, FG, supervision, GB, KPD; project administration, GB, KPD. All authors have read and agreed to the published version of the manuscript.

\section{Compliance with ethical standards}

Conflict of interest KPD and GB each possess $9.7 \%$ ownership shares of mirldetect $\mathrm{GmbH}$, Bremen, a start-up company aiming to develop a commercially available test for measuring miRs in serum. mirldetect holds a patent for the measurement of miR in body fluids at the limit of detection. AR is an employee of mirldetect $\mathrm{GmbH}$, Bremen since the beginning of 2019. All other authors declare no competing interests towards this report.

Ethical approval All procedures performed in studies involving human participants were in accordance with the ethical standards of the insti- 
tutional and/or national research committee and with the 1964 Helsinki Declaration and its later amendments or comparable ethical standards.

Informed consent Informed consent was obtained from all individual participants included in the study.

Open Access This article is licensed under a Creative Commons Attribution 4.0 International License, which permits use, sharing, adaptation, distribution and reproduction in any medium or format, as long as you give appropriate credit to the original author(s) and the source, provide a link to the Creative Commons licence, and indicate if changes were made. The images or other third party material in this article are included in the article's Creative Commons licence, unless indicated otherwise in a credit line to the material. If material is not included in the article's Creative Commons licence and your intended use is not permitted by statutory regulation or exceeds the permitted use, you will need to obtain permission directly from the copyright holder. To view a copy of this licence, visit http://creativecommons.org/licenses/by/4.0/.

\section{References}

Albers P, Albrecht W, Algaba F et al (2015) Guidelines on testicular cancer: 2015 update. Eur Urol 68:1054-1068

Almstrup K, Lobo J, Morup N et al (2020) Application of miRNAs in the diagnosis and monitoring of testicular germ cell tumours. Nat Rev Urol 17:201-213

Ates F, Malkoc E, Zor M et al (2016) Testis-sparing surgery in small testicular masses not suspected to be malignant. Clin Genitourin Cancer 14:e49-e53

Banerji JS, Odem-Davis K, Wolff EM et al (2016) Patterns of care and survival outcomes for malignant sex cord stromal testicular cancer: results from the national cancer data base. J Urol 196:1117-1122

Belge G, Hennig F, Dumlupinar C et al. (2020) Graded expression of microRNA-371a-3p in tumor tissues, contralateral testes, and in serum of patients with testicular germ cell tumor. Oncotarget 11:1462-73. https://www.oncotarget.com/article/27565/.

Bezan A, Gerger A, Pichler M (2014) MicroRNAs in testicular cancer: implications for pathogenesis, diagnosis, prognosis and therapy. Anticancer Res 34:2709-2713

Dieckmann KP, Düe W, Loy V (1988) Intrascrotal metastasis of renal cell carcinoma. Case report and review of the literature. Eur Urol 15:297-301

Dieckmann KP, Frey U, Lock G (2013) Contemporary diagnostic work up of testicular germ cell tumours. Nat Rev Urol 10:703-712

Dieckmann KP, Radtke A, Geczi L et al (2019) Serum levels of microRNA-371a-3p (M371 Test) as a new biomarker of testicular germ cell-tumors: results of a prospective multicentric study. J Clin Oncol 37:1412-1423

Dieckmann KP, Radke A, Spiekermann M et al (2017) Serum levels of microRNA 371a-3p: a sensitive and specific new biomarker for germ cell tumors. Eur Urol 71:213-220

Fankhauser CD, Grogg JB, Hayoz S et al (2019) Risk factors and treatment outcomes of 1375 patients with testicular Leydig cell tumors: analysis of published case series data. J Urol 203:949-956

Gentile G, Rizzo M, Bianchi L, Falcone M, Dente D, Cilletti M et al (2020) Testis sparing surgery for small testicular masses: retrospective analysis of a multi-center cohort. J Urol 203:760-766

Honecker F, Aparicio J, Berney D et al (2018) ESMO Consensus conference on testicular germ cell cancer: diagnosis, treatment and follow-up. Ann Oncol 29:1658-1686

Idrees MT, Ulbright TM, Oliva E et al (2017) The World Health Organization 2016 classification of testicular non-germ cell tumours: a review and update from the International Society of Urological Pathology Testis Consultation Panel. Histopathology 70:513-521

Kern SQ, Speir RW, Akgul M et al (2020) Rare benign and malignant testicular lesions: histopathology and management. Curr Opin Urol 30:235-244

Laclergerie F, Mouillet G, Frontczak A et al (2018) Testicle-sparing surgery versus radical orchiectomy in the management of Leydig cell tumors: results from a multicenter study. World J Urol 36:427-433

Lembeck AL, Puchas P, Hutterer G et al (2020) MicroRNAs as appropriate discriminators in non-specific Alpha-Fetoprotein (AFP) elevation in testicular germ cell tumor patients. Noncoding RNA 6(1):2. https://doi.org/10.3390/ncrna6010002

Livak KJ, Schmittgen TD (2001) Analysis of relative gene expression data using real-time quantitative PCR and the 2(-Delta Delta C(T)) Method. Methods 25:402-408

Lobo J, Gillis AJM, Jerónimo C et al (2019) Human germ cell tumors are developmental cancers: impact of epigenetics on pathobiology and clinic. Int J Mol Sci 20:E258. https://doi.org/10.3390/ijms20020258

Looijenga LH, Stoop H, Biermann K (2014) Testicular cancer: biology and biomarkers. Virchows Arch 464:301-313

Mooney KL, Kao CS (2018) A contemporary review of common adult non-germ cell tumors of the testis and paratestis. Surg Pathol Clin 11:739-758

Paffenholz P, Held L, Loosen SH et al (2018) Testis-sparing surgery for benign testicular masses-diagnostics and therapeutic approaches. J Urol 200:353-360

Palmer RD, Murray MJ, Saini HK et al (2010) Malignant germ cell tumors display common microRNA profiles resulting in global changes in expression of messenger RNA targets. Cancer Res 70:2911-2923

Pfaff N, Moritz T, Thum T et al (2012) miRNAs involved in the generation, maintenance, and differentiation of pluripotent cells. J Mol Med (Berl) 90:747-752

Peckham M (1988) Testicular cancer. Acta Oncol 27:439-453

Rajpert-De Meyts E, McGlynn KA, Okamoto K et al (2016) Testicular germ cell tumours. Lancet 387:1762-1774

Regouc M, Belge G, Lorch A et al (2020) Non-coding microRNAs as novel potential tumor markers in testicular cancer. Cancers 12:749. https://doi.org/10.3390/cancers 12030749

Ruf CG, Sanatgar N, Isbarn H et al (2020) Leydig-cell tumour of the testis: retrospective analysis of clinical and therapeutic features in 204 cases. World J Urol 38:2857-2862. https://doi.org/10.1007/ s00345-020-03079-1

Scandura G, Verrill C, Protheroe A et al (2017) Incidentally detected testicular lesions $<10 \mathrm{~mm}$ in diameter: can orchidectomy be avoided? BJU Int 121:575-582

Spiekermann M, Belge G, Winter N et al (2015) MicroRNA miR$371 \mathrm{a}-3 \mathrm{p}$ in serum of patients with germ cell tumours: evaluations for establishing a serum biomarker. Andrology 3:78-84

Suh MR, Lee Y, Kim JY et al (2004) Human embryonic stem cells express a unique set of microRNAs. Dev Biol 270:488-498

Syring I, Bartels J, Holdenrieder S et al (2015) Circulating serum miRNA (miR-367-3p, miR-371a-3p, miR372-3p and miR-373-3p) as biomarkers in patients with testicular germ cell cancer. J Urol 193(1):331-337. https://doi.org/10.1016/j.juro.2014.07.010

Terbuch A, Adiprasito JB, Stiegelbauer V et al (2018) MiR-371a-3p serum levels are increased in recurrence of testicular germ cell tumor patients. Int J Mol Sci 19:3130. https://doi.org/10.3390/ijms19103130

Weissbach L, Boedefeld EA, Seeber S (1985) Hodentumoren: frühzeitige Diagnose und stadiengerechte Therapie sichern den Erfolg. Dtsch Ärztebl 82:1340-1349

Publisher's Note Springer Nature remains neutral with regard to jurisdictional claims in published maps and institutional affiliations. 